\title{
Complicações e Seqüelas Neurológicas da Anestesia Regional Realizada em Crianças sob Anestesia Geral. Um Problema Real ou Casos Esporádicos?*
} Neurological Complications and Damage of Regional Block in Children
under General Anesthesia. A Real Problem or Sporadic Cases?

\author{
Verônica Vieira da Costa, TSA ${ }^{1}$, Mônica Rossi Rodrigues ${ }^{1}$, Maria do Carmo Barretto de Carvalho Fernandes²,
} Renato Ângelo Saraiva, TSA ${ }^{3}$

\begin{abstract}
RESUMO
Costa VV, Rodrigues MR, Fernandes MCBC, Saraiva RA - Complicações e Seqüelas Neurológicas da Anestesia Regional Realizada em Crianças sob Anestesia Geral. Um Problema Real ou Casos Esporádicos?
\end{abstract}

JUSTIFICATIVA E OBJETIVOS: Tem sido discutido se a técnica de anestesia regional em crianças, que na maioria das vezes é realizada após a anestesia geral, é realmente segura. Há o risco potencial de uma lesão neurológica permanente ou temporária quando o paciente não pode informar eventual parestesia ou dor, durante a realização da anestesia regional, o que gera insegurança por parte dos anestesiologistas. O objetivo deste estudo foi avaliar a prevalência de complicações e seqüelas neurológicas da anestesia regional em crianças sob anestesia geral.

MÉTODO: Numa análise prospectiva foram estudadas crianças submetidas a intervenções cirúrgicas ortopédica e plástica reparadora sob anestesia regional associada à anestesia geral. A indução e a manutenção da anestesia foram por vias venosa ou inalatória. Após anestesia geral era realizada anestesia regional e avaliada a existência de complicações imediatas, o número de punções realizadas, complicações de médio prazo e presença de seqüelas neurológicas.

RESULTADOS: Num período de 13 meses foram estudadas 499 crianças de ambos os sexos, com idade média de 6,7 anos. A maioria dos pacientes foi submetida à anestesia geral associada à peridural lombar ou caudal. A prevalência de complicação imediata foi 3,6\%, sendo a mais freqüente o sangramento no momento da punção. A prevalência de complicações em médio prazo foi 1,1\%, sendo a mais freqüente a hipoestesia e não houve seqüela neurológica de longo prazo.

CONCLUSÕES: Os resultados do presente estudo são concordantes com os de outros autores com relação à baixa prevalência de

${ }^{\star}$ Recebido do (Received from) Hospital SARAH, Brasília, DF

1. Anestesiologista do Hospital SARAH

2. Enfermeira do Hospital SARAH

3. Coordenador de Anestesiologia da Rede SARAH de Hospitais

Apresentado (Submitted) em 10 de março de 2006

Aceito (Accepted) para publicação em 08 de agosto de 2006

Endereço para correspondência (Correspondence to):

Dra. Verônica Vieira da Costa

SMHS Quadra 501 - Conjunto A

70335-901 Brasília, DF

E-mail:veve@bsb.sarah.br

(C) Sociedade Brasileira de Anestesiologia, 2006 complicações da anestesia regional em crianças sob anestesia geral, sem deixar seqüelas neurológicas. Isso pode ser atribuído ao uso de material adequado e a experiência da equipe de anestesia.

Unitermos: ANESTESIA, Pediátrica; COMPLICAÇÕES: Seqüela neurológica; TÉCNICAS ANESTÉSICAS, Regional: peridural, lombar, sacra.

\section{SUMMARY}

Costa VV, Rodrigues MR, Fernandes MCBC, Saraiva RA Neurological Complications and Damage of Regional Block in Children under General Anesthesia. A Real Problem or Sporadic Cases?

BACKGROUND AND METHODS: It has been questioned whether regional block in children, which most of the time is done under general anesthesia, is really safe. There is the potential risk of permanent or temporary neurological damage when the patient cannot complain of eventual paresthesia or pain while the block is being performed, making anesthesiologists very insecure. The aim of this study was to evaluate the prevalence of neurological complications and damage of regional block in children under general anesthesia.

METHODS: A prospective analysis of children who underwent orthopedic and reconstructive plastic surgeries under regional block associated with general anesthesia was undertaken. Anesthesia was induced and maintained by the intravenous or inhalational route. Regional block was done after general anesthesia and immediate complications, number of punctures, mean term complications, and the presence of neurological damage were evaluated.

RESULTS: Four hundred and forty-nine children, boys and girls, with a mean age of 6,7 years, were evaluated over a 13-month period. The majority of the patients underwent general anesthesia associated with epidural lumbar or caudal block. The prevalence of immediate complications was $3.6 \%$ and bleeding at the time of the puncture was the most frequent complication. The prevalence of average term complications was $1.1 \%$, and hyposthesia was the most frequent complication. There was no long-term neurological damage.

CONCLUSIONS: The results of this study are similar to those found by other authors regarding the low prevalence of complications of regional block in children under general anesthesia, without the occurrence of permanent neurological damage. This can be attributed to the use of adequate material and the experience of the anesthesia team.

Key Words: ANESTHESIA, Pediatric; ANESTHETIC TECHNIQUES: Regional: caudal, lombar, epidural; COMPLICATIONS: neurological injury. 


\section{INTRODUÇÃO}

$\mathrm{H}^{2}$ á benefícios e limitações quando se combina a técnica de anestesia regional com a de anestesia geral. A anestesia regional reduz as doses dos anestésicos gerais, produz excelente analgesia pós-operatória e diminui a resposta ao estresse em crianças e adolescentes ${ }^{1}$. Apesar desses benefícios, tem sido discutido se a realização da anestesia regional em crianças, que na maioria das vezes é realizada após a indução da anestesia geral, é realmente segura ${ }^{2}$. Há o risco potencial de uma lesão neurológica temporária ou permanente quando o paciente não pode informar eventual parestesia ou dor, durante a realização do bloqueio, que servem como sinal de alerta da proximidade da agulha ou cateter das fibras nervosas dos nervos periféricos e da medula espinhal ${ }^{3,4}$.

Em crianças a prática da anestesia regional antes da indução anestésica torna-se difícil porque elas não permitem a realização da técnica quando estão acordadas. No serviço onde o estudo foi realizado utiliza-se convencionalmente a anestesia regional após a realização da anestesia geral, em crianças, porque se acredita que a eficácia da anestesia regional diminui a dose de anestésico geral e facilita o controle de dor pós-operatória em diversos tipos de procedimentos cirúrgicos.

O objetivo deste estudo foi avaliar a prevalência de complicações e seqüelas neurológicas da anestesia regional realizada em crianças sob anestesia geral.

\section{MÉTODO}

Após aprovação do Comitê de Ética do hospital e consentimento verbal dos pais ou responsáveis, foram avaliadas, de modo prospectivo, todas as crianças submetidas à intervenções cirúrgicas ortopédica e plástica reparadora sob anestesia regional associada à geral, no período de $1^{\circ}$ de agosto de 2004 a 31 de agosto de 2005, que tivessem idade máxima de 16 anos completos. Em cada caso, o anestesiologista responsável registrava o tipo de anestesia regional associado à anestesia geral, o material utilizado, o número de tentativas, o tipo, a dose, o volume e a concentração do anestésico local, outras medicações eventualmente administradas e as complicações ocorridas durante a realização do bloqueio, bem como aquelas observadas ao longo do procedimento anestésico-cirúrgico (complicações imediatas). Os pacientes foram avaliados 24 horas após a anestesia (complicações de médio prazo) e cerca de 30 dias após (complicações de longo prazo), os prontuários foram consultados na busca de relatos de seqüelas ou complicações tardias. Essa busca foi realizada após o retorno do paciente ao ambulatório do médico assistente.

A análise estatística utilizada foi descritiva ou exploratória dos dados.

\section{RESULTADOS}

Foram estudados 449 pacientes no período de 13 meses, com idade média de 6,7 $\pm 5,2$ anos (sendo a idade mínima
6 meses e a máxima 16 anos completos). Desses, $43 \%$ (192) eram do sexo feminino e $57 \%$ (257) do sexo masculino. Foram classificados como estado físico ASA I 63\% (284 pacientes), 36,3\% (163) como estado físico ASA II e 0,4\% (2) como estado físico ASA III (Tabela I).

Tabela I - Distribuição da Freqüência do Estado Físico (ASA) entre os Pacientes Estudados

\begin{tabular}{lcc}
\hline Estado Físico & Freqüência & $\%$ \\
\hline ASA I & 284 & 63 \\
ASA II & 163 & 36 \\
ASA III & 2 & 0,4 \\
Total & 449 & 100 \\
\hline
\end{tabular}

A maioria dos pacientes (89\%) foi submetida à anestesia peridural lombar ou caudal, associada à anestesia geral. Em apenas $9 \%$ dos casos (42 pacientes), foi empregada técnica contínua. (Figura 1).

A anestesia geral foi inalatória em $93,3 \%$ casos (419), balanceada em $6,2 \%$ (28) e venosa total em $0,4 \%$ dos casos (2). $\mathrm{O}$ anestésico local mais utilizado foi a bupivacaína com vasoconstritor, sendo utilizada em $80 \%$ dos casos (Tabela II).

Tabela II - Distribuição da Freqüência dos Anestésicos e Opióides Utilizados*

\begin{tabular}{lcc}
\hline Fármacos & Freqüência & $\%$ \\
\hline Bupivacaína & 347 & 78 \\
Ropivacaína & 79 & 18 \\
Bupivacaína e fentanil & 10 & 2 \\
Lidocaína & 8 & 2 \\
Lidocaína e fentanil & 2 & 0,4 \\
Total & 446 & 100
\end{tabular}

${ }^{*} \mathrm{O}$ total de pacientes desta tabela é menor porque em três casos de complicações, como, por exemplo, perfuração acidental da dura-máter ou sangramento, a técnica foi abandonada e não foi administrado nenhum anestésico.

Em $81 \%$ dos pacientes (365) a anestesia regional foi realizada com punção única, ou seja, sucesso obtido na $1^{\text {a }}$ tentativa (Figura 2).

Em 95,1\% dos pacientes (427) não ocorreram complicações durante a realização da anestesia peridural e nem no decorrer da intervenção cirúrgica. Em seis pacientes (1,3\%) foram observadas intercorrências como falha de bloqueio e dificuldade técnica durante a sua realização. Nos 16 casos restantes $(3,6 \%)$ foram registradas complicações imediatas, sendo sangramento $(1,6 \%)$ e perfuração acidental da duramáter $(0,9 \%)$ as mais freqüentes. 


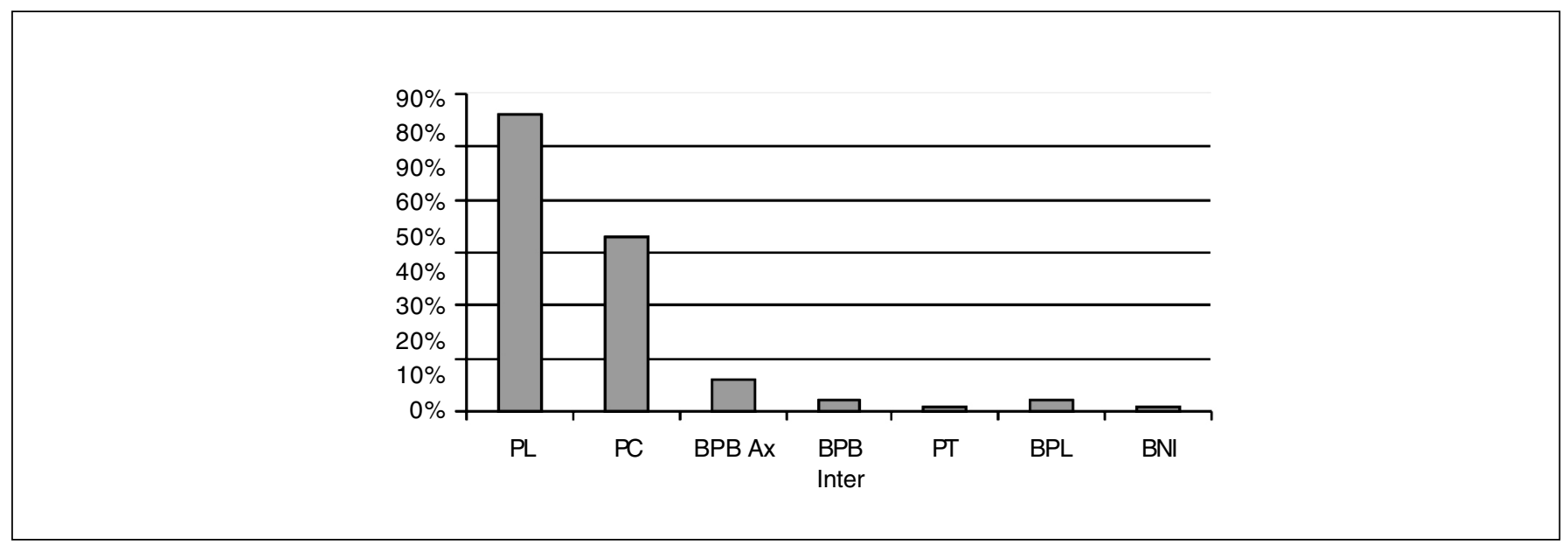

Figura 1 - Distribuição da Técnica Anestésica Utilizada. $\mathrm{PL}=$ peridural lombar; $\mathrm{PC}=$ peridural caudal; $\mathrm{BPB} \mathrm{Ax}=$ bloqueio de plexo braquial axilar; $\mathrm{BPB}=$ inter-bloqueio de plexo interescalênico; $\mathrm{PT}=$ peridural torácica; $\mathrm{BPL}=$ bloqueio peridural lombar; $\mathrm{BNI}=$ bloqueio nervo isquiático

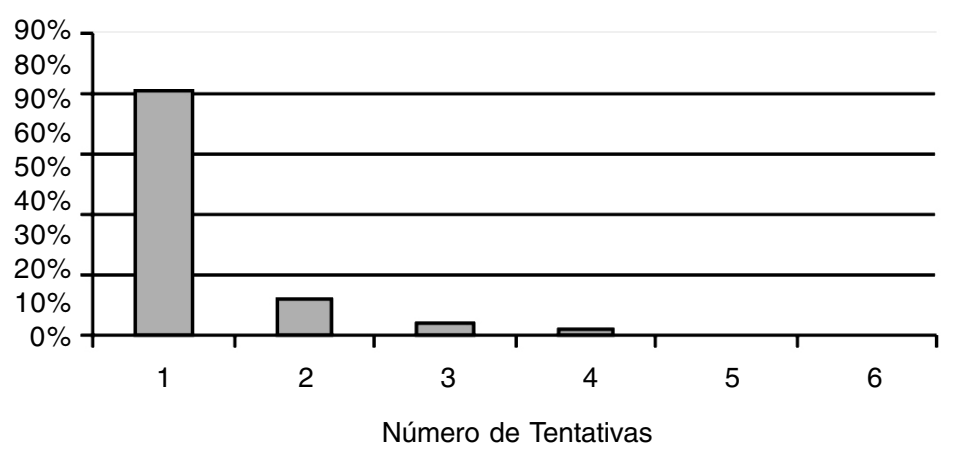

Figura 2 - Distribuição da Freqüência do Número de Punções Realizadas

Na avaliação 24 horas após o procedimento cirúrgico (complicações de médio prazo), foram observadas complicações em $1,1 \%$ dos pacientes (5). As complicações encontradas foram hipoestesia em $0,7 \%$ dos casos (3), retenção urinária em $0,2 \%$ dos pacientes (1) e cefaléia em $0,2 \%$ dos pacientes (1). A maioria dos pacientes recebeu alta 48 horas após a anestesia e nenhum retornou ao hospital com queixa relacionada ao procedimento anestésico-cirúrgico.

Cerca de 30 dias após o ato anestésico-cirúrgico os pacientes retornavam para consulta ambulatorial com o médico assistente. Nessa ocasião foi realizada consulta ao prontuário em busca de relato de complicações ou seqüelas anestésicas (complicações tardias). Não houve nenhum caso de seqüela ou complicação neurológica tardia.

\section{DISCUSSÃO}

A anestesia regional em pediatria estabeleceu-se como prática aceita e adotada em diversos serviços e vem sendo cada vez mais indicada e empregada, sobretudo nas duas últimas décadas ${ }^{1}$.
Os benefícios para o paciente, tanto no intra-operatório quanto no pós-operatório, são indiscutíveis, e incluem a diminuição das doses dos agentes anestésicos gerais (venosos e inalatórios) e da resposta ao estresse cirúrgico, maior estabilidade cardiovascular, rápido despertar, excelente analgesia pós-operatória sem risco de depressão respiratória, menor necessidade de ventilação controlada no pós-operatório de determinadas intervenções cirúrgicas, retorno mais rápido do funcionamento gastrintestinal e menor tempo de permanência na UTI ${ }^{5-7}$.

Diversos estudos prospectivos e retrospectivos demonstraram que as complicações associadas à anestesia regional em crianças são raras, na maioria das vezes não têm gravidade e são de fácil resolução ${ }^{8,9}$.

Os anestesiologistas que trabalham com crianças, de maneira geral, concordam que a realização da anestesia regional nesses pacientes é mais segura e melhor tolerada quando precedida pela indução de anestesia geral ou sedação ${ }^{2,4}$. 
A existência de relatos de casos com seqüelas neurológicas após complicações da anestesia regional em crianças sob anestesia geral faz surgir questionamentos e debates sobre qual seria a melhor conduta 4,10,11.

As causas de lesão neurológica secundária à anestesia regional são traumatismo pela agulha, hematoma peridural, coleções líquidas, abscesso peridural, administração de substâncias neurotóxicas ${ }^{12-14}$.

Os principais fatores de risco para a ocorrência de lesão neurológica são parestesia durante o posicionamento da agulha ou cateter, dor à injeção, doença neurológica preexistente e a presença de dificuldade técnica no momento da realização do bloqueio ${ }^{3,4}$.

A falta de dados que afirmem o contrário e o peso da prática clínica, sugerem que a maioria dos bloqueios de pequenos e grandes nervos periféricos e dos bloqueios de plexo, com a provável exceção do bloqueio de plexo braquial por via interescalênica, pode ser seguramente realizado sob sedação ou anestesia geral superficial com ventilação espontânea. Os estimuladores de nervos auxiliam na localização de nervos periféricos e aumentam os índices de sucesso dos bloqueios, mas não há evidência de que reduzam o potencial de lesão nervosa no paciente acordado ou anestesiado ${ }^{11}$.

Anestesias peridural lombar e caudal simples, como são administradas abaixo do cone medular, não podem causar lesão direta na medula espinhal ${ }^{11}$.

Na peridural torácica, as peculiaridades anatômicas das vértebras torácicas tornam a punção mais difícil e a medula espinhal está mais susceptível às lesões.

A inserção de cateter peridural nos níveis torácico e lombar superior em pacientes anestesiados e sob efeito de bloqueadores neuromusculares, quando a medula espinhal pode ser lesada e a presença de parestesia não pode ser notada, é sem dúvida mais perigosa ${ }^{15}$.

No caso relatado por Kasai e col. ${ }^{14}$ uma criança de 9 anos que seria submetida a apendicectomia de urgência evoluiu com quadro de edema na medula espinhal, que abrangia os níveis $T_{10}$ a $T_{12}$ após a realização de anestesia peridural em $T_{10}-T_{11}$ sob anestesia geral. Na primeira tentativa de localização do espaço peridural ocorreu perfuração acidental da duramáter. Optou-se então por uma segunda abordagem no mesmo espaço, desta vez sem acidentes, e foram administrados $5 \mathrm{~mL}$ de bupivacaína a $0,25 \%$. O exame neurológico no pós-operatório evidenciou hipoestesia nos segmentos lombares de $\mathrm{L}_{4}$ a $\mathrm{S}_{1}$ e no membro inferior esquerdo. Os sintomas neurológicos regrediram lenta e progressivamente. Em outro relato, Aldrete ${ }^{15}$ descreveu o caso de uma criança de 7 anos com programação de uma fundoplicatura a Nissen. Sob anestesia geral e com bloqueio neuromuscular, um cateter peridural foi instalado em $\mathrm{T}_{8}-\mathrm{T}_{9}$. A punção peridural foi obtida após múltiplas tentativas. No intra-operatório duas injeções de anestésico local, a primeira de $4 \mathrm{~mL}$ de lidocaína a 1,5\% e a segunda de $5 \mathrm{~mL}$ de bupivacaína a $0,25 \% 45$ minutos depois, resultaram em hipotensão arterial. $\mathrm{Na}$ sala de recuperação após nova injeção de $5 \mathrm{~mL}$ de bupi- vacaína a 0,25\% pelo cateter observou-se hipotensão arterial e apnéia temporária. Déficits sensitivos e motores foram detectados no dia seguinte. O paciente evoluiu com siringomielia de $T_{5}$ a $T_{10}$, disestesia de $T_{6}$ a $T_{10}$, diminuição da força no membro inferior esquerdo e disfunções vesical e intestinal. Não há estudos prospectivos, comparativos com distribuição aleatória dos pacientes que comparem os riscos relativos da anestesia regional realizada em pacientes conscientes e anestesiados ${ }^{16}$.

Tsui e col. ${ }^{17}$ relataram um caso de lesão medular após anestesia peridural torácica realizada no paciente adulto acordado. No serviço onde este trabalho foi realizado todas as anestesias regionais em crianças são feitas após indução da anestesia geral. Este estudo demostrou que nenhuma complicação grave ocorreu e nenhum paciente apresentou seqüela neurológica. O que confirma os resultados de outros autores ${ }^{8,9}$. Todas as anestesias foram realizadas por profissionais com mais de cinco anos de experiência e o material utilizado é próprio para cada faixa etária. Em apenas $3 \%$ casos foram feitas mais de três tentativas durante a realização da anestesia regional.

Quando o anestesiologista opta por efetuar anestesia regional em uma criança sob anestesia geral, que não está apta a informar sobre a ocorrência de dor ou parestesia, outros cuidados e precauções devem ser adotados antes e durante a realização da técnica.

A avaliação pré-anestésica cuidadosa deve buscar informações que indiquem ou descartem a possibilidade de doenças neurológicas ou vasculares preexistentes. Para a realização de anestesia regional com segurança, são essenciais cautela durante a realização da anestesia, utilização de material adequado para idade, atenção ao que ocorre com a agulha e ao fato de que quando existe qualquer dificuldade técnica há maior probabilidade de complicações. Diante de dificuldades técnicas suspeitas devem-se evitar tentativas repetidas, potencialmente traumáticas e buscar alternativas. A presença de movimentos musculares reflexos, maior resistência à movimentação da agulha e mais importante, qualquer resistência à injeção sinalizam para a presença de contato com estruturas nervosas. Eventuais complicações que possam evoluir para lesão permanente devem ser prontamente reconhecidas e tratadas. Profissionais em formação devem ser supervisionados de modo adequado porque algumas nuances práticas podem não ser percebidas a tempo ${ }^{11}$.

A anestesia regional em crianças sob anestesia geral é mais confortável para o paciente, oferece mais segurança e melhores condições técnicas para o anestesiologista. $\mathrm{O}$ estudo realizado demonstrou baixa prevalência de complicações, complicações leves, sem seqüelas neurológicas e é possível questionar se elas poderiam ter ocorrido independentemente do paciente estar anestesiado ou consciente ${ }^{17}$. Outros estudos obtiveram resultados semelhantes ${ }^{8,9}$. Ainda assim a indicação deve ser criteriosa, e a realização dos procedimentos com base na convicção de que os benefícios serão maiores que os riscos ${ }^{11,18,19}$. 


\section{AGRADECIMENTOS}

Os autores agradecem à estatística Érika Carvalho Pires Arci, do Controle de Qualidade do Hospital Sarah Brasília Centro, pela valiosa contribuição no processamento dos dados e análise estatística.

\section{Neurological Complications and Damage of Regional Block in Children under Ge- neral Anesthesia. A Real Problem or Sporadic Cases?}

Verônica Vieira da Costa, TSA, M.D.; Mônica Rossi Rodrigues; Maria do Carmo Barretto de Carvalho Fernandes; Renato Ângelo Saraiva, TSA, M.D.

\section{INTRODUCTION}

Combining regional block with general anesthesia has benefits and limitations. Regional block reduces the dose of general anesthetics, produces excellent postoperative analgesia, and decreases the response to stress in children and teenagers ${ }^{1}$. Despite the benefits, it has been questioned whether regional block in children, which is usually done under general anesthesia, is really safe ${ }^{2}$. There is the potential risk of temporary or permanent neurological damage when the patient cannot complaint of paresthesia or pain while the blockade is being performed, which is a warning sign that the needle or catheter is close to the nerve fibers of the peripheral nerves and spinal cord ${ }^{3,4}$.

In children, regional block before anesthetic induction is difficult to do, since this patient population does not allow it to be done when they are awake. At the department where this study was conducted, regional block is always done after general anesthesia in children because we believe that the efficacy of the regional block decreases the dose of the general anesthetic, making it easier to control postoperative pain in different types of surgical procedures.

The objective of this study was to evaluate the prevalence of neurological complications and injuries of regional block in children under general anesthesia.

\section{METHODS}

After approval by the Ethics Committee of the hospital and verbal consent by the parents or guardians, a prospective study was done including every child, under 16 years old, undergoing orthopedic and reparatory plastic surgeries under regional block associated with general anesthesia from August 01, 2004 to August 31, 2005. In every case the anesthesiologist recorded the type of regional block associated with the general anesthesia, the used material, number of attempts, type, dose, volume, and concentration of local anesthetic, other drugs administered, and complications during the block, as well as those observed during the anesthetic-surgical procedure (immediate complications). Patients were evaluated 24 hours after the anesthesia (average term complications), and about 30 days after the surgery (long term complications) patients' charts were examined for reports of late injuries or complications. This research was done after the patient returned to the outpatient clinic. Descriptive or exploratory statistical analysis of the data was performed.

\section{RESULTS}

Four hundred and forty-nine patients, with a mean age of 6,7 \pm 5.2 years (between 6 months and 16 years), were studied over a 13-month period. Forty-three percent of those (192) were girls and $57 \%$ (257) boys. Sixty-three per cent $(284$ patients) were classified as physical status ASA I, $36.3 \%$ (163) ASA II, and 0.4\% (2) ASA III (Table I).

Table I - Distribution of the Physical Status (ASA) Among Study Patients

\begin{tabular}{lcc}
\hline Physical Status & Frequency & $\%$ \\
\hline ASA I & 284 & 63 \\
ASA II & 163 & 36 \\
ASA III & 2 & 0.4 \\
Total & 449 & 100 \\
\hline
\end{tabular}

Most patients (89\%) underwent lumbar or caudal epidural block associated with general anesthesia, and in only 9\% (42 patients) the continuous method was used (Figure 1). Inhalational general anesthesia was used in $93.3 \%$ of the cases (419), balanced general anesthesia in $6.2 \%$ (28), and total intravenous anesthesia in $0.4 \%$ of the cases (2).

Bupivacaine with vasoconstrictor was the local anesthetic used in $80 \%$ of the cases (Table II).

In $81 \%$ of the patients (365) regional block was done with a single puncture, i.e., it was successful in the first attempt (Figure 2).

Table II - Distribution of the Anesthetics and Opioids Used

\begin{tabular}{lcc}
\hline Drugs & Frequency & $\%$ \\
\hline Bupivacaine & 347 & 78 \\
Ropivacaine & 79 & 18 \\
Bupivacaine and fentanyl & 10 & 2 \\
Lidocaine & 8 & 2 \\
Lidocaine and fentanyl & 2 & 0.4 \\
Total & 446 & 100 \\
\hline
\end{tabular}

The total number of patients in this table is smaller because in three cases of complications, e.g., accidental puncture of the dura mater or bleeding, the technique was discontinued, and anesthetics were not administered. 


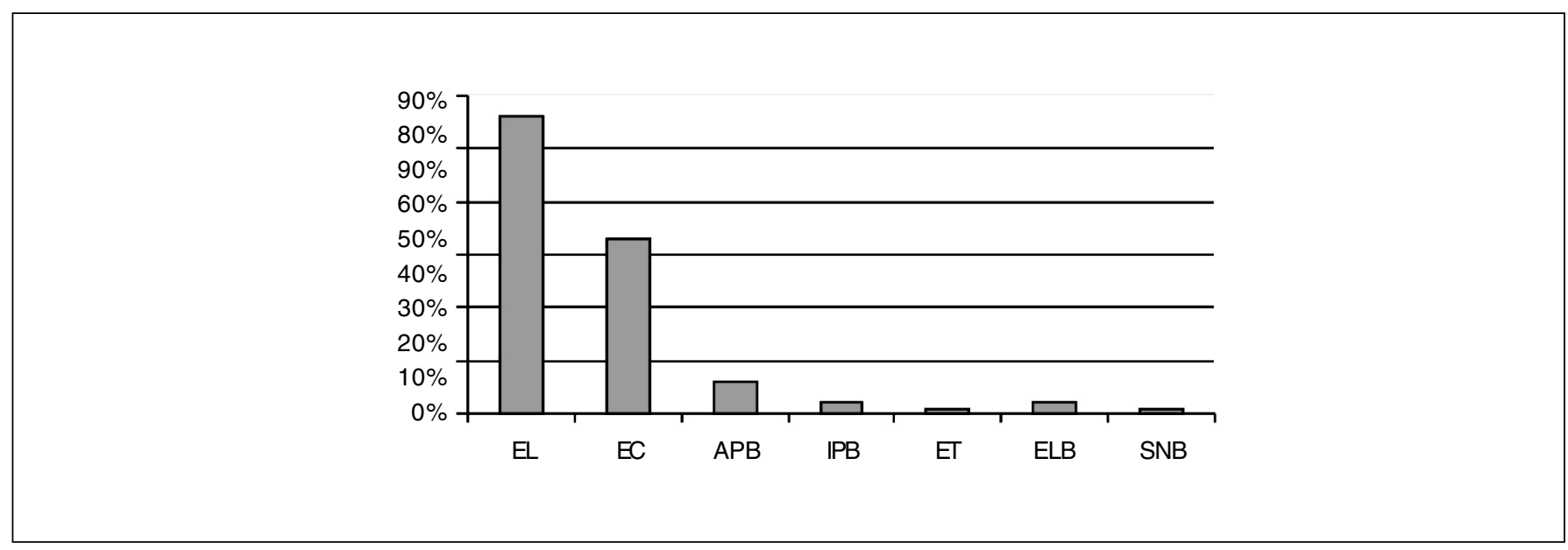

Figure 1 - Anesthetic Techniques Used. EL = epidural lumbar; EC = epidural caudal; APB = axillary plexus block; IPB = interscalene plexus block; $\mathrm{ET}=$ epidural thoracic; ELB = epidural lumbar block; SNB = sciatic nerve block

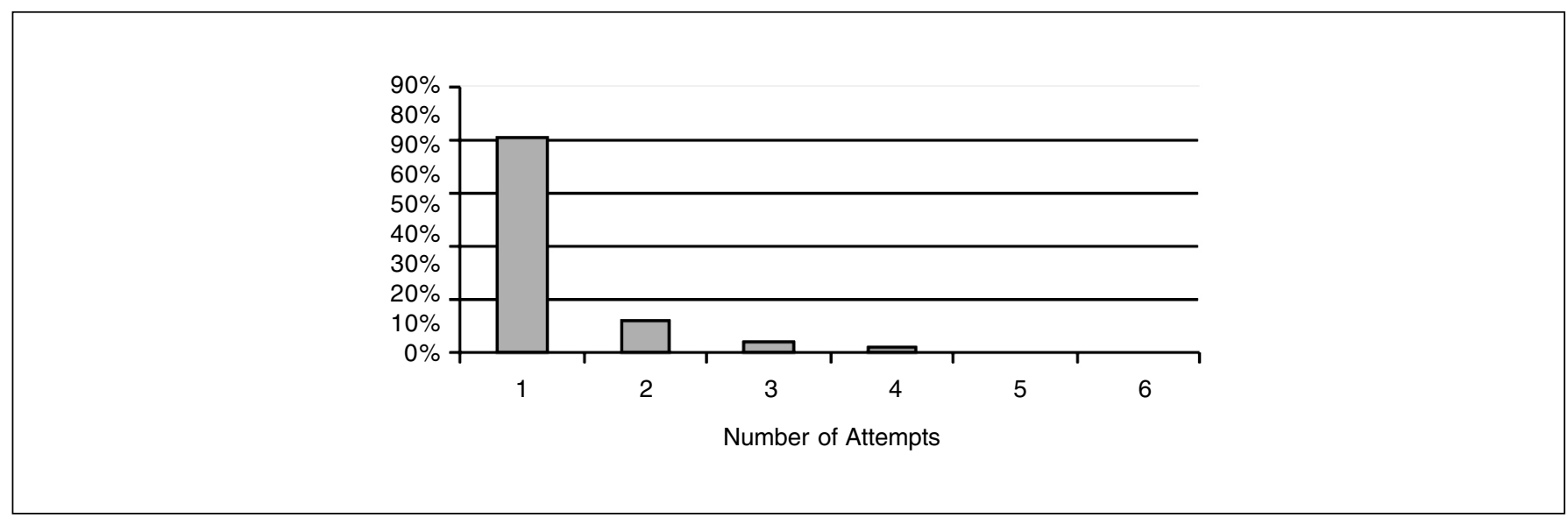

Figura 2 - Frequency Distribution of Number of Punctures Done.

There were no complications during the epidural block and the surgical procedure in $95.1 \%$ of the patients (427). Six patients (1.3\%) presented complications, such as block failure and technical difficulty for its administration. The remaining 16 cases $(3.6 \%)$ presented immediate complications, of which bleeding (1.6\%) and accidental puncture of the dura mater $(0.9 \%)$ were the most frequent.

Twenty-four hours after the surgery (mean term complications), $1.1 \%$ of the patients (5) presented complications, such as hypoesthesia in $0.7 \%$ of the cases (3), urinary retention in $0.2 \%$ of the patients (1), and headache in $0.2 \%$ of the cases (1). Most patients were discharged from the hospital 48 hours after the surgery, and no one returned to the hospital with complaints regarding the anesthetic-surgical procedure.

About 30 days after the surgery, patients returned to the outpatient clinic for follow-up. At that time, patients' charts were reviewed for reports of complications or damage (late complications). There were no cases of late neurological complication or damage.

\section{DISCUSSION}

Regional block in pediatrics is the accepted standard practice, being adopted in several departments, being increasingly indicated and used, especially in the last two decades ${ }^{1}$.

The benefits for the patients during both the intraoperative and the postoperative periods are unquestionable, and include decreased dose of general anesthetics (intravenous and inhalational), decreased response to surgical stress, improved hemodynamic stability, fast awakening, excellent postoperative analgesia without the risk of respiratory depression, reduction in the need for postoperative controlled ventilation in certain surgeries, faster recovery of gastrointestinal function, and reduced length of stay in the ICU ${ }^{5-7}$.

Several prospective and retrospective studies have demonstrated that the complications associated with regional block in children are rare, most of the time are not severe, and are easy to solve ${ }^{8,9}$.

In general, anesthesiologists who work with children agree that regional blocks in those patients are safer and better 
tolerated when preceded by general anesthesia or sedation ${ }^{2,4}$.

Reports of neurological deficits after complications of regional block in children under general anesthesia raised doubts and fueled the debate about what would be the best approach in this population ${ }^{4,10,11}$.

The causes of neurological damage secondary to regional block include needle trauma, epidural hematoma, fluid collections, epidural abscess, and the administration of neurotoxic substances ${ }^{12-14}$.

The main risk factors for neurological lesion are paresthesia during positioning of the needle or catheter, pain during the injection, preexisting neurological disease, and technical difficulties at the time of the block ${ }^{3,4}$.

The lack of contradicting data and the clinical experience suggest that most blocks of small and large peripheral nerves and plexus, with the possible exception of the interscalene brachial plexus blockade, can be safely done under sedation or after superficial general anesthesia with spontaneous ventilation. Nerve stimulators help localizing peripheral nerves and increase the success rates, but there is no evidence that they reduce the potential for nervous lesion in the awaken or anesthetized patient ${ }^{11}$.

Since epidural or simple caudal epidural blocks are administered below the spinal cone, they cannot cause direct damage to the spinal cord ${ }^{11}$.

In the thoracic epidural block, the anatomical peculiarities of the thoracic vertebrae hinder the puncture and, therefore, the spinal cord is more prone to lesions.

The introduction of the epidural catheter at the thoracic and superior lumbar levels in anesthetized patients and under the effects of neuromuscular blockers is unquestionably more dangerous, since the spinal cord can be damaged and the presence of paresthesia cannot be detected ${ }^{15}$.

In the case reported by Kasai et al. ${ }^{14}$, a 9-year old child undergoing urgent appendectomy developed spinal cord edema from $T_{10}$ to $T_{12}$ after epidural block under general anesthesia. There was an accidental perforation of the dura mater in the first attempt to localize the epidural space. It was then decided to attempt a second time in the same space, which this time was uneventful, being administered $5 \mathrm{~mL}$ of $0.25 \%$ bupivacaine. The postoperative neurological exam demonstrated hypoesthesia in the lumbar segments, from $L_{4}$ to $S_{1}$, and in the left lower limb. Neurological symptoms reverted slowly and progressively.

Aldrete ${ }^{15}$ reported the case of a 7-year old child scheduled for a Nissen fundoplication. Under general anesthesia and good neuromuscular blockade, an epidural catheter was placed in $\mathrm{T}_{8}-\mathrm{T}_{9}$. The epidural puncture was successful after multiple attempts. During the operative period, two injections of local anesthetic, $4 \mathrm{~mL}$ 1.5\% lidocaine followed, after 45 minutes, by $5 \mathrm{~mL} 0.25 \%$ bupivacaine, resulted in blood hypotension. In the posthanestetic recovery unit, after another dose of $5 \mathrm{~mL}$ $0.25 \%$ bupivacaine through the catheter, the patient developed hypotension and temporary apnea. Sensitive and mo- tor deficits were detected the following day. The patient developed syringomyelia from $T_{5}$ to $T_{10}$, dysesthesia from $T_{6}$ to $\mathrm{T}_{10}$, decreased strength in the left lower limb, and bladder and intestinal dysfunction.

There are no prospective, randomized studies comparing the relative risks of regional block in conscious and anesthetized patients ${ }^{16}$.

Tsui et al. ${ }^{17}$ reported one case of spinal cord injury after thoracic epidural block in a conscious, adult patient.

In our department, regional blocks in children are done after induction of general anesthesia. This study demonstrated that there were no severe complications and there were no cases of neurological damage. This corroborates the results of other studies ${ }^{8,9}$. Anesthesia was performed by anesthesiologists with more than five years experience and the material used was appropriate for each age Group. In only 3\% of the cases more than three attempts were made during the regional block.

When the anesthesiologist decides for a regional block in a child under general anesthesia, who is not able to complaint about pain or paresthesia, other precautions should be taken before and during the block.

Careful preanesthetic assessment should look for information that indicate or exclude the possibility of preexisting neurological or vascular disease. For a safe regional block it is necessary to be careful during the procedure, use material that is adequate for the patient's age, pay attention to the needle and to the fact that any technical difficulty increases the risk of complications. Faced with the suspicion of technical difficulties, one should avoid several attempts, which are potentially traumatic, and look for alternatives. The presence of reflex muscle movements, greater resistance to the introduction of the needle, and, most importantly, any resistance to the injection, indicate the presence of contact with nervous structures. Eventual complications that might evolve to permanent injury should be identified and treated immediately. Residents should be adequately supervised because certain practical nuances might not be noticed in time ${ }^{11}$.

Regional block in children is more comfortable for the patient, safer, and offer better technical conditions to the anesthesiologist. This study demonstrated the low prevalence of complications, mild complications, without neurological damage, and one might question if they would have happened whether the patient was anesthetized or conscious ${ }^{17}$. Other studies presented similar results ${ }^{8,9}$. Nevertheless, the indication of regional block under general anesthesia in children should be judicious, and the procedure should be done based on the conviction that the benefits are greater than the risks ${ }^{11,18,19}$.

\section{ACKNOWLEDGEMENTS}

The authors wish to thank the statistician Érika Carvalho Pires Arci of the Hospital Sarah Brasília Centro Quality Control for her invaluable contribution in the processing of the data and statistical analysis. 


\section{REFERÊNCIAS - REFERENCES}

01. Bosenberg A - Pediatric regional anesthesia update. Paediatr Anaesth, 2004;14:398-402.

02. Bosenberg AT, Ivani G - Regional anaesthesia - children are different. Paediatr Anaesth, 1998;8:447-450.

03. Bromage PR, Benumof $\mathrm{JL}-$ Paraplegia following intracord injection during attempted epidural anesthesia under general anesthesia. Reg Anesth Pain Med, 1998;23:104-107.

04. Krane EJ, Dalens BJ, Murat I et al - The safety of epidurals placed during general anesthesia. Reg Anesth Pain Med, 1998; 23:433-438.

05. Anand KJ, Carr DB - The neuroanatomy neurophysiology, and neurochemistry of pain, stress and analgesia in newborns and children. Pediatr Clin North Am, 1989;36:795-822.

06. McNeely JK, Faber NE, Rusy LM et al - Epidural analgesia improves outcome following pediatric fundoplication. A retrospective analysis. Reg Anesth, 1997;22:16-23.

07. Ivani G, Tonetti F, Mossetti V - Update on postoperative analgesia in children. Minerva Anestesiol, 2005;71:501-505.

08. Wood CE, Goresky GV, Klassen KA et al - Complications of continuous epidural infusions for postoperative analgesia in children. Can J Anaesth, 1994;41:613-620.

09. Giaufre E, Dalens B, Gombert A - Epidemiology and morbidity of regional anesthesia in children: a one-year prospective survey of the French-Language Society of Pediatric Anesthesiologists. Anesth Analg, 1996;83:904-912.

10. Bromage PR - Masked mischief. Reg Anesth, 1996; 21:(Suppl6): 62-63.

11. Fischer HB - Regional anaesthesia - before or after general anaesthesia? Anaesthesia, 1998;53:727-729.

12. Katz N, Hurley R - Epidural anesthesia complicated by fluid collection within the spinal cord. Anesth Analg, 1993;77:1064-1065.

13. Absalom AR, Martinelli G, Scott NB - Spinal cord injury caused by direct damage by local anaesthetic infiltration needle. $\mathrm{Br} J$ Anaesth, 2001;87:512-515.

14. Kasai T, Yaegashi K, Hirose M et al - Spinal cord injury in a child caused by an accidental dural puncture with a single-shot thoracic epidural needle. Anesth Analg, 2003;96:65-67.

15. Aldrete JA, Ferrari $\mathrm{H}-$ Myelopathy with syringomyelia following thoracic epidural anaesthesia. Anesth Intensive Care, 2004; 32:100-103.

16. Horlocker TT, Abel MD, Messick JM et al - Small risk of serious neurologic complications related to lumbar epidural catheter placement in anaesthetized patients. Anaesth Analg, 2002; 96:1547-1552.

17. Tsui BC, Armstrong $\mathrm{K}-$ Can direct spinal cord injury occur without paresthesia? A report of delayed spinal cord injury after epidural placement in an awake patient. Anesth Analg, 2005; 101:1212-1214.

18. Martinez-Garcia E, Pelaez E, Roman JC et al - Transverse myelitis following general and epidural anaesthesia in a paediatric patient. Anaesthesia, 2005;60:921-923.

19. Drasner K - Thoracic epidural anesthesia: asleep at the wheal? Anesth Analg, 2004;99:578-579.

\section{RESUMEN}

Costa VV, Rodrigues MR, Fernandes MCBC, Saraiva RA - Complicaciones y Secuelas Neurológicas de la Anestesia Regional Realizada en Niños bajo Anestesia General. ¿Un Problema Real o Casos Esporádicos?

JUSTIFICATIVA Y OBJETIVOS: Han sobrevenido discusiones sobre si la técnica de anestesia regional en niños, que en la mayoría de las veces se realiza después de la anestesia general, sea realmente segura. Existe el riesgo potencial de una lesión neurológica permanente o temporal cuando el paciente no puede informar la eventual parestesia o dolor, durante la realización de la anestesia regional, lo que genera inseguridad por parte de los anestesiólogos. El objetivo de este estudio fue el de evaluar la prevalencia de complicaciones y de secuelas neurológicas de la anestesia regional en niños bajo anestesia general.

MÉTODO: En un análisis prospectivo se estudiaron niños sometidos a intervenciones quirúrgicas ortopédica y plástica reparadora bajo anestesia regional asociada a la anestesia general. La inducción y el mantenimiento de la anestesia fueron por vía venosa o por inhalación. Después de la anestesia general se realizaba anestesia regional y se evaluaba la existencia de complicaciones inmediatas, el número de punciones realizadas, complicaciones de medio plazo y la presencia de secuelas neurológicas.

RESULTADOS: En un período de 13 meses se estudiaron 499 niños de los dos sexos, con edad promedio entre 6 y 7 años. La mayoría de los pacientes se sometió a la anestesia general asociada a la peridural lumbar o caudal. La prevalencia de complicación inmediata fue de un 3,6\%, siendo la más frecuente el sangramiento al momento de la punción. La prevalencia de complicaciones en medio plazo fue de un $1,1 \%$, siendo la más frecuente la hipoestesia y no hubo secuela neurológica a largo plazo.

CONCLUSIONES: Los resultados del presente estudio están a tono con los de otros autores con relación a la baja prevalencia de complicaciones de la anestesia regional en niños bajo anestesia general, sin dejar secuelas neurológicas. Eso puede ser atribuido al uso de material adecuado y a la experiencia del equipo de anestesia. 